WARSZTATY Z GEOGRAFII TURYZMU

$\begin{array}{ll}\text { ISBN 978-83-7525-713-7 } & \text { s. } 21-47\end{array}$

http://dx.doi.org/10.18778/7525-713-7.03

Andrzej KOWALCZYK

Uniwersytet Warszawski

\title{
RECEPTA NA SUKCES? ZNACZENIE KONCEPCJI WATERFRONTU DLA ROZWOJU TURYSTYKI W MIASTACH PRZYKŁAD Z HONGKONGU
}

\begin{abstract}
Wstęp
Truizmem jest stwierdzenie, że rozwój turystyki i rekreacji ma istotny wpływ na funkcjonowanie dużych miast i zmiany w przestrzeni miejskiej. Według CLARKA i in. (2001), w społeczeństwach postindustrialnych miasto nie jest miejscem produkcji, ale konsumpcji. Dlatego też wspomniani autorzy traktują miasto jako entertainment machine, co w wolnym przekładzie można przetłumaczyć jako „urządzenie rozrywkowe” („maszyna rozrywki”). Ich zdaniem takie podejście wynika z nowej funkcji, jaką pełnią miasta w dobie globalizacji. W cytowanej pracy można przeczytać: „konsumpcja jest napędzana przez lokalną specyfikę: kawiarnie, galerie sztuki, walory przyrodnicze/architektoniczne oraz spostrzeganie miasta $\mathrm{w}$ kategoriach estetycznych określają miasto jako jedyną w swoim rodzaju atrakcję. Turystyka jest trzecim co do znaczenia działem światowej gospodarki i przyciąganie turystów jest ważnym zajęciem dla władz lokalnych, które w tym celu budują nowe stadiony, parki, muzea, centra kongresowe i tym podobne urządzenia, mając nadzieję zwabić turystów z bliska i daleka." (CLARK i in. 2001, s. 3). Podobny pogląd reprezentują inni autorzy, podając iż $\mathrm{np} . \mathrm{w}$ programach rewalo-
\end{abstract}


ryzacji dzielnic Fillmore w San Francisco oraz Greenwich Village w Nowym Jorku istotne znaczenie miało poddanie modernizacji (a następnie ich promocja) klubów jazzowych, co miało sprzyjać gentryfikacji tych dzielnic (HUGHES 2003, s. 170).

Ścisłe związki między kulturalno-turystyczną funkcją wielkiego miasta a jego atrakcyjnością dla potencjalnych inwestorów dostrzega także VOASE (1997, s. 237), który pisze (w wolnym tłumaczeniu): „miasto sprzyjające spędzaniu wolnego czasu lub miasto znaczące pod względem kulturalnym jest w świecie postindustrialnym widziane jako miasto pełne sukcesów"1.

Konsekwencją coraz większego znaczenia w dużych miastach obiektów i usług związanych z szeroko rozumianą turystyką i rekreacją (włączając $\mathrm{w}$ to kulturę, rozrywkę, sport, centra handlowe) jest pojawienie się dzielnic nazywanych recreational business districts (RBD). Bardzo często powstają one w rejonach miast, które wcześniej pełniły inne funkcje - często przemysłowe, portowe itp. Aby mogły one powstać, konieczne jest podjęcie wielu działań, nie tylko kosztownych, ale i zajmujących wiele czasu, które polegają na takim zagospodarowaniu przestrzeni wielkomiejskiej, aby ich centra mogły służyć nowym celom. Na ogół wspomniane działania są objęte terminem "rewitalizacja”, która jest rozumiana, jako „sekwencja planowanych działań mających na celu ożywienie gospodarcze oraz zmianę struktury przestrzennej i funkcjonalnej zdegradowanych obszarów miasta" (KACZMAREK 2001, s. 16).

\section{Koncepcje teoretyczne związane z wprowadzaniem funkcji turystyczno-rekreacyjnych do centrów wielkich miast}

Jak twierdzi COHEN-HATTAB (2004, s. 280), można wyróżnić następujące modele struktury przestrzennej miasta o rozwiniętej funkcji turystycznej:

- model miasta turystyczno-historycznego G. J. Ashwortha i J. E. Tunbridge'a (tourist-historic city model);

- model rozwoju centralnej dzielnicy turystycznej (CTD) C. A. Stansfielda i E. J. Rickerta (central tourist district model) oraz „dzielnicy aktywności turystycznej" (TBD) D. Getza (tourist business district model);

- model turystycznych przestrzeni funkcjonalnych miasta D. Burtenshawa $\mathrm{i}$ in. (tourist town's functional spaces model);

\footnotetext{
1 „,[...] the leisured city, or the cultural city, is the successful city in the post-industrial world".
}

22 | WARSZTATYZ GEOGRAFI TURYZM 
- model rozmieszczenia usług noclegowych G. J. Ashwortha (accommodation service model).

Model proponowany przez ASHWORTHA i TUNBRIDGE'A (2000) najbardziej odpowiada sytuacji występującej w miastach dużych i średniej wielkości w Europie. Zgodnie z nim w pierwszej fazie rozwoju miasta w jego centralnej części powstaje dzielnica śródmiejska (CBD), o dominacji funkcji handlowych. Z czasem część placówek handlowo-usługowych przenosi się z dotychczasowego centrum na jego obrzeża, co powoduje powstanie odrębnych części centralnych - historycznego centrum oraz dzielnicy handlowej. W trzeciej fazie rozwoju miasta na pograniczu historycznego centrum i dzielnicy handlowej pojawia się wyraźnie zaznaczona dzielnica turystyczna. Tendencja ta utrzymuje się, przy czym w fazie ostatniej, równolegle do ekspansji przestrzennej części uznawanej za część historyczną miasta oraz powiększaniu się dzielnicy handlowej, w śródmiejskiej części miasta zaczyna się pojawiać proces gentryfikacji, którego przejawem jest m.in. ponowny rozwój funkcji mieszkaniowej.

Koncepcja istnienia w miastach części, którą można nazwać „dzielnicą turystyczną" (central tourist district, CTD) dotyczy zarówno miast mniejszych, jak i wielkich aglomeracji. Według COHEN-HATTABA (2004, s. 283), jak również autorów tej koncepcji (STANSFIELD, RICKERT 1970), CTD pojawia się w wyniku rozwoju część miasta, którą można określić mianem recreational business district (RBD). Zazwyczaj CTD powstaje bądź wewnątrz administracyjno-handlowej dzielnicy środmiejskiej (CBD), bądź też w jej sąsiedztwie. Jej charakterystyczną cechą jest to, iż na jej obszarze skoncentrowane są zarówno atrakcje, jak i usługi turystyczne. Koncepcja CTD została szeroko opisana przez BURTENSHAWA i in. (1991), którzy przyjęli założenie, że powstanie i właściwe funkcjonowanie „dzielnicy aktywności turystycznej” może mieć miejsce wówczas, gdy turyści i inni odwiedzający mają możność poruszania się po centralnej części aglomeracji pieszo.

Konsekwencją coraz większego znaczenia w miastach urządzeń i usług związanych z szeroko rozumianą turystyką jest pojawienie się dzielnic nazywanych "dzielnicami aktywności rekreacyjnej” (recreational business districts, RBD). Według GETZA (1993), pojęciem bliskim określeniu recreational business district jest termin „dzielnica aktywności turystycznej” (tourism business district, TBD), który jego zdaniem lepiej oddaje charakter zmian w przestrzeni miejskiej pod wpływem turystyki niż określenie RBD. Zdaniem cytowanego autora, określenie recreational business district może być używane w sytuacjach, gdy przemiany przestrzeni miejskiej pod wpływem turystyki mają jeszcze niewielkie rozmiary, natomiast termin tourism business district dotyczy sytuacji, gdy turystyka zaczyna być wiodącym czynnikiem powodują- 
cym zmiany w przestrzeni miasta. Czynnikami sprzyjającymi powstaniu TBD są skupione $\mathrm{w}$ śródmieściu atrakcje turystyczne (D. Getz wymienia m.in. zabytki architektury, obiekty kulturalne, ośrodki konferencyjne, placówki handlowe, wydarzenia mogące zainteresować turystów itp.), funkcje centralne wynikające $z$ istnienia CBD (funkcja handlowa i administracyjna, liczne biura itd.) oraz dobrze rozwinięte usługi (np. sieć transportowa, usługi hotelarskie i gastronomiczne, informacja turystyczna). Wszystko to sprawia, że zarówno walory i zagospodarowanie turystyczne, jak również ruch turystyczny - z powodu dobrej dostępności przestrzennej - koncentrują się właśnie $\mathrm{w}$ centrum. W zewnętrznej strefie aglomeracji znajdują się jedynie nieliczne walory oraz usługi, które D. Getz określa mianem peryferyjnych.

Z pozoru propozycja TBD autorstwa D. Getza jest zbieżna z przedstawioną wcześniej koncepcją C. A. Stansfielda i E. J. Rickerta. Wydaje się jednak, że istotą różnicy między koncepcją CTD a koncepcją TBD jest przywiązywanie przez C. A. Stansfielda i E. J. Rickerta większej wagi do występowania w mieście atrakcji turystycznych, podczas gdy D. Getz większy nacisk kładzie na usługi turystyczne.

W literaturze polskiej omówienie przedstawionych tu koncepcji zawarte zostało m.in. w publikacjach KOWALCZYKA (2005), KOWALCZYKA i DEREK (2010) oraz WŁODARCZYKA (2009). Dlatego też uznano, że w niniejszym opracowaniu nie ma potrzeby poświęcania im więcej miejsca. $\mathrm{W}$ zamian, $\mathrm{z}$ racji myśli przewodniej zawartej w tytule prezentowanego tekstu, postanowiono szerzej opisać inne koncepcje - koncepcję festival market place (FMP) oraz koncepcję waterfrontu.

\subsection{Koncepcja FMP}

Koncepcja festival market place (FMP), którą można przetłumaczyć jako koncepcje "miejsca rozrywkowo-handlowego", jest w pewnym stopniu bliska opisanej wyżej koncepcji „dzielnicy aktywności turystycznej”. Obie koncepcje różnią się jednak tym, iż o ile koncepcje CTD, TBD, czy RBD opisują stan zastany (są przez to koncepcjami a posteriori), koncepcja festival market place jest koncepcją planistyczną (a więc koncepcją a priori), która jest szeroko stosowana we współczesnej urbanistyce.

Koncepcja festival market place została sformułowana przez planistów w Stanach Zjednoczonych i dotyczy głównie dużych miast północnoamerykańskich, w których w latach 70. i 80. XX w. zaczęto gruntownie zmieniać charakter śródmieścia, wyburzając dawne, często zdekapitalizowane w sensie technicznym i zdegradowane $\mathrm{w}$ sensie społecznym dzielnice, $\mathrm{w}$ miejsce

24 WARSZTATYZ GEOGRAFI TURYZMU 
których zaczęto wznosić nowoczesne obiekty użyteczności publicznej, np. centra handlowo-rozrywkowe, sale koncertowo-kongresowe, hotele itp. (GETZ 1993, GRAVARI-BARBAS 1998, LAW 1992). W Stanach Zjednoczonych miastami, w których zastosowano $\mathrm{w}$ praktyce koncepcję miejsca rozrywkowo-handlowego są m.in. Baltimore, Boston, Chicago, Jacksonville, Miami, Nowy Jork, Nowy Orlean, Portland i Seattle², a z miast poza Ameryką Północną elementy FMP można dostrzec $\mathrm{w}$ Londynie (np. w rejonie tzw. London Docklands), Liverpoolu i w kilku innych dużych miastach brytyjskich oraz w Sydney, Singapurze, Szanghaju, Kapsztadzie, a także w Victorii i Koulunie (Hongkong). W miastach tych w przebudowanych śródmieściach powstały liczne hotele, na ogół występujące w skupieniach i mające często charakter centrów kongresowo-hotelowych z rozbudowanym zapleczem gastronomiczno-rozrywkowym, licznymi sklepami itp. (np. w Baltimore i Bostonie), galerie handlowo-rozrywkowe (czy coraz częściej rozrywkowo-handlowe), placówki muzealne, sale koncertowe oraz wiele innych obiektów służących rekreacji, rozrywce, kulturze, jak również zakupom. W Polsce przykładami nawiązującymi do koncepcji FMP są przede wszystkim galerie handlowo-usługowo-rozrywkowe Silesia City Center (2005 r.) w Katowicach oraz Centrum Manufaktura (2006 r.) w Łodzi.

Za autora koncepcji festival market place należy uznać Jamesa W. Rouse, założyciela działającej w latach 1939-2004 firmy (od 1956 r. deweloperskiej) Rouse Company (przejętej przez General Growth Properties), która zajmowała się budowaniem i administrowaniem wielu tego rodzaju obiektów w Stanach Zjednoczonych ${ }^{3}$.

Pod pewnymi względami (od strony formy) za pierwowzór dla niektórych obiektów wzniesionych w nawiązaniu do koncepcji festival market place można uznać powstałe w 1922 r. centrum handlowe Country Club Plaza w Kansas City (stan Missouri) ${ }^{4}$. Za główne cele przyświecające koncepcji festival market place, która $\mathrm{z}$ powodzeniem została zastosowana $\mathrm{w}$ wielu dużych aglomeracjach miejskich, należy uznać dążenie do osiągnięcia:

- celów ekonomiczno-społecznych, poprzez rozwijanie usług handlowych, gastronomicznych, rozrywkowych, hotelarskich;

- celów społeczno-kulturalnych, dzięki rozwijaniu usług kulturalnych, organizowaniu ogólnodostępnych (na ogół związanych z wolnym wstępem) przestrzeni dla plenerowych wydarzeń kulturalno-rozrywkowych;

${ }^{2}$ W 2011 r. na terenie Stanów Zjednoczonych było co najmniej 31 obiektów uznawanych za wzniesione zgodnie z założeniami koncepcji festival market place (http://en.wikipedia.org/wiki/Festival_market place, 15.10.2011).

${ }^{3} \mathrm{http}: / /$ en.wikipedia.org/wiki/Rouse_Company (15.10.2011).

${ }^{4}$ http://en.wikipedia.org/wiki/Country_Club_Plaza (15.10.2011). 
- cele rekreacyjno-sportowe, poprzez organizowanie terenów zielonych i rozwijanie infrastruktury rekreacyjno-sportowej.

Pierwszym projektem zrealizowanym zgodnie z założeniami koncepcji FMP był ukończony w 1976 r. i znajdujący się w śródmieściu Bostonu (stan Massachussetts) Faneuil Hall Marketplace. Powstał on w sąsiedztwie zabytkowej Faneuil Hall (1762 r. $)^{5}$ i składa się z trzech równolegle stojących budynków z początku XIX w. (South Market, Quincy Market, North Market), w których mieszczą się przede wszystkim sklepy i restauracje, jak również sala widowiskowa (w budynku Faneuil Hall). Innymi najbardziej znanymi obiektami powstałymi jako festival market place są Harborplace (którego rdzeń stanowi centrum rozrywkowo-handlowego Harborplace \& The Gallery) w Baltimore (stan Maryland, 1980 r.), South Street Seaport w Nowym Jorku (stan Nowy Jork, 1983 r.) oraz Jacksonville Landing w Jacksonville i Bayside Marketplace w Miami (w obu przypadkach stan Floryda i w obu przypadkach inwestycje zostały oddane do użytku w 1987 r.).

Istotą projektów zrealizowanych według koncepcji FMP jest przyjęcie założenia, że pełnione przez nie rozliczne funkcje nie powinny ograniczać się do usług świadczonych w obiektach zamkniętych (budynkach), ale powinny również obejmować przyległe do nich tereny. Inaczej mówiąc - według twórców koncepcji festival market place ścisłe centra wielkich miast powinny przypominać dzięki pełnionym przez siebie funkcjom nieco agorę $\mathrm{w}$ miastach starożytnej Grecji czy rynek w miastach europejskich w dobie średniowiecza i renesansu. Nieprzypadkowo więc koncepcję mającą zmienić oblicze centrów wielkich miast nazwano festival market place. W tym miejscu nasuwa się pewna refleksja; w literaturze przedmiotu poświęconej FMP na ogół są podawane przykłady ze Stanów Zjednoczonych.

Na podstawie licznych przykładów zastosowania koncepcji FMP w praktyce można uznać, że wzniesione obiekty pełnią przede wszystkim następujące funkcje (kolejność funkcji różni się nieco w zależności od obiektu):

- handlowo-usługowa, która jest na ogół najbardziej znacząca, gdyż większość obiektów ma charakter komercyjny;

- gastronomiczną;

- kulturalno-rozrywkową (głównie dzięki istnieniu sal kinowych, ale często również są to sale teatralne, koncertowe, sale zabaw dla dzieci);

- kulturalno-edukacyjną (muzea);

- kulturalno-handlową (galerie sztuki, sale wystawowe);

- rekreacyjna, przede wszystkim dzięki odpowiednio urządzonym terenom zieleni;

${ }^{5} \mathrm{http} / / / \mathrm{www}$. faneuilhallmarketplace.com/?q=history (17.10.2011).

26 | WARSZTATYZ GEOGRAFI TURYZMU 
- rekreacyjno-sportową (obecność infrastruktury umożliwiającej aktywny wypczynek - kluby fitness, korty tenisowe, boiska do gier zespołowych, sale do gry w squasha, lodowiska, tory do gry w kręgle itp.);

- turystyczna, głównie dzięki obecności hoteli oraz biur świadczących usługi turystyczne;

- administracyjno-biurową; gdyż często zdarza się, że w niektórych obiektach (zazwyczaj na wyższych kondygnacjach, nad sklepami, restauracjami itp.) mieszczą się siedziby firm - np. banków, firm ubezpieczeniowych, korporacji o globalnym zasięgu;

- inne (np. związane z opieką medyczną).

Kończąc omawianie koncepcji festival market place należy wspomnieć jeszcze o jednej - niebagatelnej - kwestii. Chociaż czasami realizowane zgodnie z jej założeniami projekty mają komercyjny charakter, na ogół funkcjonują one zgodnie $\mathrm{z}$ zasadami partnerstwa publiczno-prywatnego, a bardzo często powstają $\mathrm{w}$ wyniku wprowadzenia w życie strategii rozwoju uchwalonych przez władze miejskie. Niekiedy są to ogólne strategie rozwoju miasta (np. w Atlancie), ale coraz częściej istotną w nich rolę odgrywa rozwijanie $\mathrm{w}$ mieście funkcji związanych z turystyką i rekreacją (np. w Baltimore).

\subsection{Koncepcja waterfrontu}

Inną koncepcją która pod niektórymi względami jest na tyle bliska koncepcji festival market place, że w wielu przypadkach trudno je od siebie odróżnić, jest koncepcja waterfrontu, czy też miejskich obszarów nadwodnych (TöLLE 2010). Podobnie, jak i koncepcję FMP należy uznać ją za koncepcję urbanistyczną o charakterze koncepcji a priori.

Zgodnie z najprostszą definicją termin „waterfront” oznacza "tereny $\mathrm{w}$ miastach ulokowane nad naturalnymi zbiornikami wodnymi (morze, jezioro, większa rzeka), które są obszarami stykowymi między strukturami miejskimi a terenami portowymi lub dawnymi terenami portowo-przemysłowymi"6. W praktyce urbanistycznej termin "waterfront" jest często stosowany $\mathrm{w}$ odniesieniu do obszarów miejskich, które zostały poddane rewitalizacji i pełnią obecnie inne funkcje niż pierwotnie. Wśród projektów zrealizowanych w nawiązaniu do koncepcji waterfrontu wyróżnia się projekty:

- monofunkcyjne (np. Sydney Opera, 1973 r., China Hong Kong City, 1988 r., Osaka Suntory Museum, 1994 r.) - zwykle o funkcjach handlo-

${ }^{6}$ http://pl.wikipedia.org/wiki/Waterfront (15.10.2011). 
wych, biurowo-administracyjnych, kulturalnych, turystycznych, rekreacyjnych, sportowych, a także rozrywkowych;

- wielofunkcyjne (np. Vancouver Canada Place-Granville Island, 1979 r., Singapore Boat Quay-Clarke Quay-East Coast Park, 1985 r., Chicago Navy Pier, 1995 r.) - które poza podanymi wcześniej funkcjami, pełnią na ogół również funkcję mieszkaniową.

Z powyższych rozważań wynika, że w wielu sytuacjach - gdy dotyczy to terenów położonych nad naturalnymi zbiornikami wodnymi lub kanałami (co często ma miejsce $\mathrm{w}$ miastach w Wielkiej Brytanii) - zagospodarowanie stref nadwodnych może być zgodne z założeniami koncepcji festival market place. Tak stało się we wspomnianych już Baltimore, Bostonie (chociaż obiekty Faneuil Hall Marketplace nie znajdują się bezpośrednio nad woda, tworzące je zabudowania były pierwotnie ulokowane ze względu na bliskość portu), Jacksonville, Nowym Jorku w Stanach Zjednoczonych, jak również $\mathrm{w}$ aglomeracjach szeroko opisanych w pracy TöLlE (2010), zwłaszcza w Bilbao i w Hamburgu (dzielnica HafenCity). W tym miejscu na szczególną uwagę zasługuje opinia wyrażona przez cytowanego autora (TÖLlE 2010, s. 46), iż „przykład Bilbao pokazuje powodzenie strategicznego planowania na poziomie metropolitalnym, a także konieczność szybkiego działania $\mathrm{w}$ tych ramach oraz znaczenia skutecznych negocjacji w strukturach publiczno-prywatnych".

\section{Zastosowanie rozwiązań proponowanych w koncepcji FMP i koncepcji waterfrontu - przykład Tsim Sha Tsui Waterfront w Koulunie (Specjalny Region Administracyjny Hongkong, Chiny)}

Wśród wymienionych wcześniej aglomeracji miejskich, w których dużą rolę w rozwoju obszarów nadwodnych odegrały koncepcje festival market place i waterfrontu na szczególne wyróżnienie zasługują Victoria i Koulun w Hongkongu, gdyż specyficzne warunki geograficzne i uwarunkowania historyczne spowodowały, iż w miastach tych idea waterfrontu zaczęła być w praktyce realizowana zanim została sformułowana jako koncepcja planistyczna. Poczynając od końca XIX w. na wyspie Hongkong (na której leży Victoria), nieco później na półwyspie Koulun, a jeszcze później w różnych miejscach tzw. Nowych Terytoriów (które od 1898 r. wchodziły w skład byłej kolonii brytyjskiej Hongkong, a obecnie - razem z wyspą Hongkong, półwyspem Koulun i przybrzeżnymi wyspami - wchodzi w skład Specjalnego Regionu 
Administracyjnego Hongkong w Chinach) podjęto prace polegające na pozyskiwaniu nowych terenów w wyniku osuszania i zasypywania przybrzeżnych akwenów morskich, głównie zatok. Tym samym co jakiś czas, po ustabilizowaniu się gruntu, na sąsiadujących $\mathrm{z}$ morzem nowych fragmentach lądu przystępowano do wznoszenia nowych budynków publicznych i domów mieszkalnych, wytyczania ulic i budowania wiaduktów, zakładania parków, skwerów itp., co oznacza, iż znaczna część współczesnej zabudowy miejskiej (zwłaszcza w Victorii, w nieco mniejszym stopniu w Koulunie), obecnie leżąca nawet kilkaset metrów od linii brzegowej, to w swoim czasie obszary nadwodne.

Nic więc dziwnego, że po pojawieniu się w światowej urbanistyce głosów, że tereny nadwodne należy zagospodarowywać zgodnie z zasadami bliskimi koncepcji festival market place, władze Hongkongu uznały, iż od tej pory rozwój obszarów pozyskanych od morza powinien i w Victorii czy Koulunie, i w innych rejonach regionu nawiązywać zarówno do koncepcji FMP, jak i waterfrontu (Planning study on the Harbour... 2003). Tendencja ta którą można było zauważyć już wcześniej - nasiliła się w ostatnich latach. Jako przykład mogą służyć inwestycje oddane do użytku po 2000 r. W końcu 2003 r. w położonej nad oddzielającą wyspę Hongkong od półwyspu Koulun cieśniną Victoria Harbour centralnej części Victorii (dzielnica Central) ukończono budowę dwóch wieżowców (po $420 \mathrm{~m}$ ) składających się na International Finance Centre, w sąsiedztwie których oddano do użytku 5-gwiazdkowy hotel (1000 pokoi) oraz nowoczesne centrum handlowo-rozrywkowe IFC Mall. Niedługo potem, poczynając od stycznia 2004 r., zaczęto urządzać każdego dnia wieczorem przez kilkanaście minut widowisko typu „światło i dźwięk" nazwane "Symfonia świateł” ("A symphony of lights"), w trakcie którego turyści mają możliwość podziwiania $\mathrm{z}$ nadmorskiej promenady $\mathrm{w}$ dzielnicy Tsim Sha Tsui w Koulunie i statków wycieczkowych pływających po Victoria Harbour, oświetlanych przez kilka tysięcy reflektorów, 18 wieżowców znajdujących się w nadwodnej części Victorii (w dzielnicach Central, Wan Chai i Causeway Bay) (Hong Kong fabulous... 2004). Jak wynika z tab. 1 w której przedstawiono plany z lat 2003-2004 obejmujących główne inwestycje mające podnieść atrakcyjność turystyczną Hongkongu w następnych latach - część tych zamierzeń (Tsim Sha Tsui Promenade, dawna Marine Police Headquarters Compound, rejon West Kowloon 7 i Observation Wheel,

${ }^{7}$ Do 2011 r. obszar ten (niedawno pozyskany od morza) był tymczasowo zamieniony na tereny zielone z prowizoryczną infrastrukturą rekreacyjno-sportową (korty tenisowe, boiska, place zabaw dla dzieci). Jednak $\mathrm{w}$ najbliższych latach największym przedsięwzięciem inwestycyjnym $\mathrm{w}$ tej części Koulunu będzie realizacja projektu West Kowloon Cultural District, który został opracowany w 2010 r. przez biuro Foster \& Partners światowej sławy architekta N. Fostera. Zgodnie z przedstawionym (i przyjętym w marcu 
które jednak do końca 2011 r. nie zostało zbudowane) dotyczyła obiektów położonych bezpośrednio nad morzem lub w niewielkiej od niego odległości, a więc można przyjąć, że miały one powstać na terenach nadwodnych zabudowywanych bądź przekształcanych zgodnie z koncepcją waterfrontu (tab. 1).

Tabela 1. Najważniejsze inwestycje zaplanowane w związku z dążeniem do podniesienia atrakcyjności turystycznej Hongkongu (Chiny)

\begin{tabular}{|c|c|c|c|}
\hline Inwestycja & $\begin{array}{l}\text { Rok } \\
\text { ukon- } \\
\text { czenia }\end{array}$ & Lokalizacja & Uwagi \\
\hline $\begin{array}{l}\text { Asia World- } \\
\text { Expo }\end{array}$ & 2005 & $\begin{array}{l}\text { Rejon lotniska Hong } \\
\text { Kong International } \\
\text { Airport (wyspa Lantau) }\end{array}$ & $\begin{array}{l}\text { Zbudowanie } 10 \text { hal wystawowych o powierz- } \\
\text { chni } 70000 \mathrm{~m}^{2} \text { (największa z nich - o powierz- } \\
\text { chni } 10880 \mathrm{~m}^{2} \text { - miała pomieścić } 13500 \text { osób) }\end{array}$ \\
\hline $\begin{array}{l}\text { Hong Kong } \\
\text { Disneyland }\end{array}$ & 2005 & Wyspa Lantau & $\begin{array}{l}\text { Zbudowanie na } 126 \text { ha parku rozrywki oraz } \\
\text { dwóch hoteli }\end{array}$ \\
\hline $\begin{array}{l}\text { Hong Kong } \\
\text { Wetland Park }\end{array}$ & 2005 & $\begin{array}{l}\text { Okolice bagien Mai Po } \\
\text { Inner Deep Bay } \\
\text { (Nowe Terytoria) }\end{array}$ & $\begin{array}{l}\text { Na I etapie na powierzchni } 64 \text { ha miał być } \\
\text { zorganizowany park ornitologiczny, na II etapie } \\
\text { miało powstać centrum edukacyjne }\left(10000 \mathrm{~m}^{2}\right)\end{array}$ \\
\hline $\begin{array}{l}\text { Kolejka linowa } \\
\text { na szczyt Ngong } \\
\text { Ping }\end{array}$ & 2006 & Wyspa Lantau & $\begin{array}{l}\text { Zbudowanie liczącej 5,7 km kolejki linowej, która } \\
\text { miała ułatwić dotarcie do posagu Buddy i klasz- } \\
\text { toru Po Lin }\end{array}$ \\
\hline $\begin{array}{l}\text { Observation } \\
\text { Wheel }\end{array}$ & 2006 & $\begin{array}{l}\text { Budynek portu } \\
\text { pasażerskiego } \\
\text { (Ocean Terminal) }\end{array}$ & Liczące $75 \mathrm{~m}$ koło widokowe \\
\hline $\begin{array}{l}\text { Tsim Sha Tsui } \\
\text { Waterfront } \\
\text { Promenade }\end{array}$ & 2007 & $\begin{array}{l}\text { Dzielnica Tsim Sha Tsui } \\
\text { (Koulun) }\end{array}$ & $\begin{array}{l}\text { Urządzenie strefy pieszej oraz terenów rozryw- } \\
\text { kowo-kulturalnych i rekreacyjnych }\end{array}$ \\
\hline $\begin{array}{l}\text { Hotel w dawnej } \\
\text { siedzibie policji } \\
\text { morskiej }\end{array}$ & 2007 & $\begin{array}{l}\text { Najstarsza część } \\
\text { Koulunu } \\
\text { (Koulun) }\end{array}$ & $\begin{array}{l}\text { Urządzenie hotelu w poddanym rewaloryzacji } \\
\text { dawnym budynku policji morskiej (Marine Police } \\
\text { Headquarters Compound) z } 1884 \mathrm{r} \text {. }\end{array}$ \\
\hline $\begin{array}{l}\text { Centrum } \\
\text { turystyczno- } \\
\text { rozrywkowe }\end{array}$ & 2009 & $\begin{array}{l}\text { Najstarsza część Victorii } \\
\text { (wyspa Hongkong) }\end{array}$ & $\begin{array}{l}\text { Zorganizowanie centrum turystyczno-rozryw- } \\
\text { kowego w poddanej rewaloryzacji dawnej sie- } \\
\text { dzibie policji (Central Police Station) przy } \\
\text { Hollywood Road z } 1864 \text { r. }\end{array}$ \\
\hline West Kowloon & 2012 & $\begin{array}{l}\text { Zachodnia część } \\
\text { Koulunu } \\
\text { (Koulun) }\end{array}$ & $\begin{array}{l}\text { Utworzenie na obszarach pozyskanych do mo- } \\
\text { rza nowej dzielnicy o rozwiniętych funkcjach } \\
\text { kulturalno-rozrywkowych i handlowych }\end{array}$ \\
\hline
\end{tabular}

Źródło: opracowano na podstawie Hong Kong fabulous... (2004), Hong Kong future... (2003), Hong Kong museums... (2003).

2011 r.) projektem, na powierzchni 23 ha mają powstać opera, muzeum sztuki współczesnej, sale koncertowe, hala widowiskowa z 15000 miejsc, centrum wystawienniczo-targowe, a także budynki biurowe i mieszkalne (KK 2010). 
Chociaż w ostatnich latach w kilku rejonach Victorii i Koulunu zostały ukończone lub są $\mathrm{w}$ trakcie realizacji nowe projekty polegające na zagospodarowaniu terenów nadmorskich $\mathrm{z}$ uwzględnieniem funkcji turystyczno-rekreacyjnej, najciekawszym spośród nich jest bez wątpienia proces zagospodarowywania Tsim Sha Tsui Waterfront w południowej części półwyspu Koulun. Jest on interesujący przede wszystkim z następujących powodów. Po pierwsze, obejmuje obszary byłego dworca kolejowego i przylegających do niego terenów portowych, które zostały zastąpione przez biurowce, galerie handlowe, hotele, restauracje, muzea, co może być potraktowane jako działania na rzecz restrukturyzacji funkcji miejskich. Po drugie, proces przemian przestrzenno-funkcjonalnych w południowej części półwyspu Koulun objął tereny, które w tym czasie w znacznym stopniu straciły dotychczasowe znaczenie ( $w$ związku $\mathrm{z}$ nowymi technologiami w organizacji transportu morskiego, jak również z powodu napięcia politycznego związanego z sytuacją wewnętrzną w Chińskiej Republice Ludowej i pogorszeniem się jej relacji z innymi państwami świata) i uległy degradacji. Tym samym należy go uznać za przykład rewaloryzacji przestrzeni miejskiej. Po trzecie, w ramach podjętych działań w niektórych przypadkach starano się zachować charakterystyczne dla dawnego Koulunu zabytki architektoniczne (wieżę zegarową dawnego dworca kolejowego Kowloon Station oraz - co prawda znajdująca się już poza terenami dawnego portu, ale w bezpośrednim jego sąsiedztwie pochodzącą z XIX w. dawną siedzibę Marine Police Headquarters Compound), które odnowiono. Tę dbałość o zachowanie dziedzictwa kulturowego można uznać za dowód działań podjętych w celu rehabilitacji (czy też renowacji) elementów przestrzeni miejskiej. Ponadto, ponieważ obecnie tereny składające się na Tsim Sha Tsui Waterfront należą do najczęściej odwiedzanych przez turystów przyjeżdżających do Hongkongu, a także mieszkańców regionu, podjęte przez władze i prywatnych inwestorów działania przyczyniły się do rewitalizacji tej części Koulunu.

Tereny tworzące obecną dzielnicę Tsim Sha Tsui zostały przejęte przez Wielką Brytanię razem z całym półwyspem Koulun w 1860 r. Już w 1884 r. w pobliżu najbardziej na południe wysuniętej części półwyspu, na niewysokim wzniesieniu (Signal Hill), powstała siedziba brytyjskiej policji portowej (Marine Police Headquarters Compound), a w kilka lat z niedalekiej przystani zaczęły kursować promy spółki Star Ferry, która wkrótce zdominowała przewozy przez Victoria Habour między Koulunem a położonym na wyspie Hongkong miastem Victoria. Jeszcze pod koniec XIX w. obszar położony w południowej części półwyspu Koulun zaczął być zamieniany na tereny portowe. 


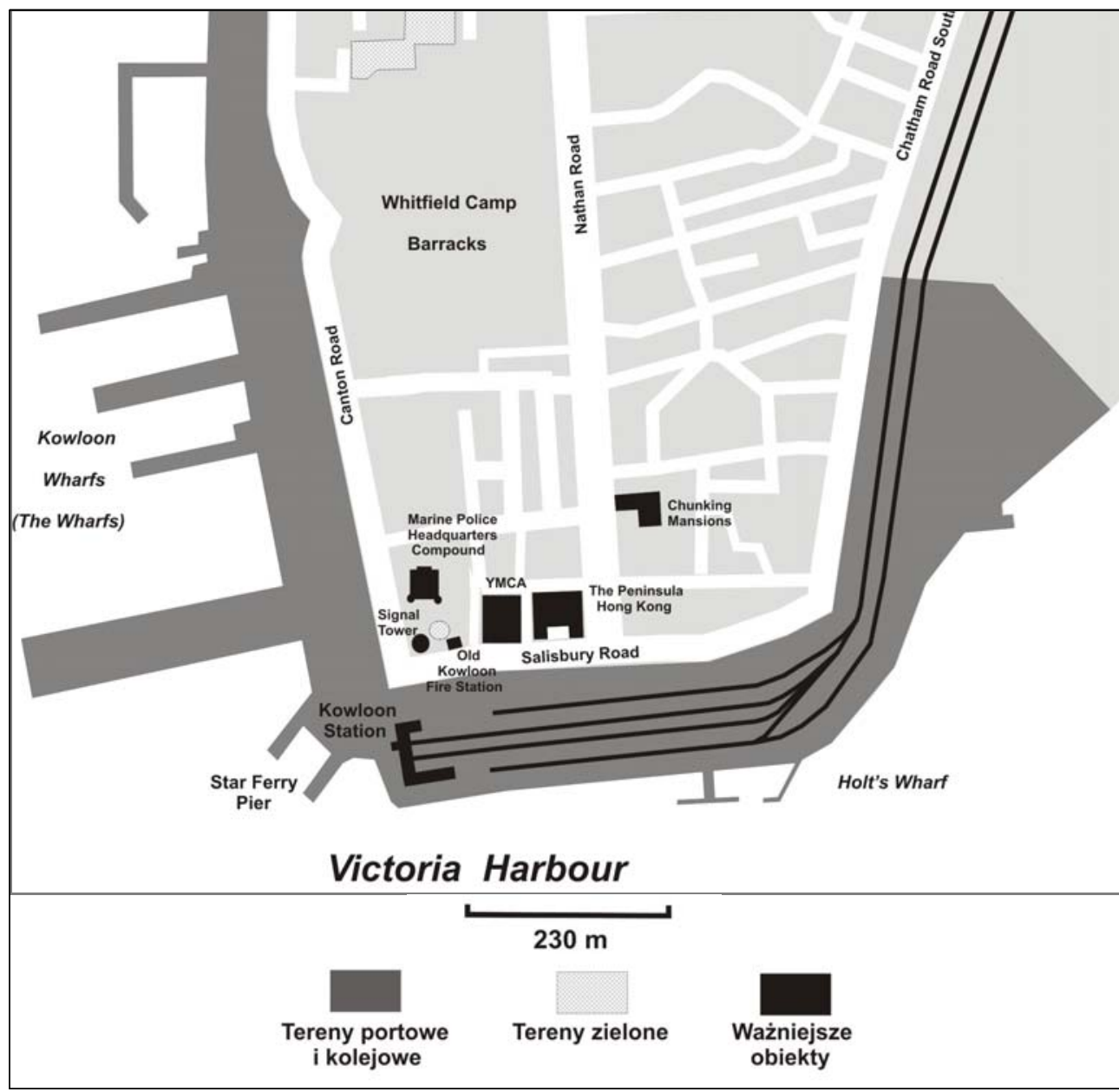

Rys. 1. Dzielnica Tsim Sha Tsui w Koulunie (Hongkong) przed rozpoczęciem inwestycji związanych z zastąpieniem funkcji portowych i kolejowych funkcjami turystyczno-rekreacyjnymi i kulturalnymi (połowa lat 60. XX w.) Źródło: opracowanie autora

W tym samym czasie, również w 1910 r., do Koulunu doprowadzono z Kantonu (obecnie Kuangczou, chiń. Guangzhou) linię kolejową (Kowloon-Canton Railway), która początkowo kończyła bieg na dworcu w dzielnicy Hung Hom (na północny wschód od Tsim Sha Tsui). Jednak po kilku latach została ona doprowadzona do Tsim Sha Tsui, gdzie - naprzeciw Marine Police Headquarters Compound i w sąsiedztwie przystani promowej (Star 
Ferry Pier) - w latach 1915-1916 oddano do użytku dworzec kolejowy Kowloon Station, wyróżniający się spośród sąsiadującej zabudowy wysoką na $44 \mathrm{~m}$ wieżą zegarową której zwieńczenie służyło jednocześnie jako znak świetlny dla statków. ${ }^{8}$ Lokalizacja nowej stacji końcowej Kowloon-Canton Railway nie była przypadkowa, gdyż znalazła się dokładnie pośrodku między terenami portowymi należącymi do The Hong Kong \& Kowloon Wharf and Godown Company Ltd. (nazywanymi The Wharf) oraz konsorcjum Butterfield \& Swire i Blue Funnel Line (Holt's Wharf) (rys. 1).

Zbudowanie dworca kolejowego oraz wchodzących w jego skład licznych rozjazdów i bocznic kolejowych znacznie przyspieszyło rozwój dzielnicy Tsim Sha Tsui. Poza dalszą rozbudową urządzeń portowych, w odległości $200 \mathrm{~m}$ od Kowloon Station oddano do użytku w 1928 r. luksusowy hotel The Peninsula Hong Kong (należący do przybyłej z Indii rodziny Kadoorie) $)^{9}$. Jego lokalizacja nie była przypadkowa, gdyż w tym czasie w Tsim Sha Tsui gwałtownie rozwijał się handel, czemu towarzyszło powstawanie nowych budynków mieszkalnych, obiektów administracyjnych, kulturalnych itp. Zajęcie Hongkongu przez Japonię i okupacja japońska (lata 19411945), mimo pewnych zniszczeń spowodowanych przez naloty lotnictwa amerykańskiego, nie wpłynęły na spadek znaczenia Tsim Sha Tsui $\mathrm{w}$ życiu społeczno-gospodarczym Hongkongu. Napływ migrantów z Chin (po powstaniu w 1949 r. Chińskiej Republiki Ludowej) pociągnął nawet za sobą rozwój Koulunu, m.in. z powodu przeniesienia się do Hongkongu z Kantonu i Szanghaju wielu przedsiębiorstw należących do chińskich rodzin, które opuściły Chiny w obawie przed przejęciem ich majątku przez władze komunistyczne. Jednym z przejawów czasu prosperity było ukończenie w $1961 \mathrm{r}$. 17-piętrowego Chunking Mansions, budynku łączącego w sobie dom mieszkalny z tanim hotelem, w którym mieściły się także sklepy, a nawet niewielkie zakłady rzemieślnicze ${ }^{10}$.

Powstanie Chungking Mansions można uznać za ostatnią ważniejszą inwestycję "starego" (pomijając czasy sprzed przybycia Brytyjczyków) Koulunu. Niedługo po jego ukończeniu dzielnica Tsim Sha Tsui zaczęła ulegać daleko idącym przemianom, które miały trwać ponad 40 lat. Wspomniane wcześniej zmiany $\mathrm{w}$ technologiach związanych $\mathrm{z}$ transportem morskim, wobec których urządzenia portowe w południowym Koulunie okazały się przestarzałe, jak również spadek znaczenia transportu kolejowego sprawiły, że w połowie lat 60. XX w. koncern The Hong Kong \& Kowloon Wharf and

${ }^{8}$ http://en.wikipedia.org/wiki/Clock_Tower,_Hong_Kong (20.10.2011).

${ }^{9} \mathrm{http}$ ://en.wikipedia.org/wiki/The_Peninsula_Hong_Kong (20.10.2011)

${ }^{10} \mathrm{http}: / /$ en.wikipedia.org/wiki/Chungking_Mansions (20.10.2011). 
Godown Company Ltd. podjął decyzję zawieszenia działalności związanej z funkcjonowaniem portu i przekształcenia należących do niego terenów w nowoczesną dzielnicę biurowo-hotelowo-handlową. Nowa dzielnica miała nosić nazwę Harbour City, co wyraźnie nawiązywało do jej położenia nad cieśniną Victoria Habour. Jednak zanim na miejscu dotychczasowych magazynów portowych zaczęto wznosić pierwsze biurowce i hotele, $\mathrm{w}$ roku 1966 oddano do użytku nowy dworzec morski (Ocean Terminal), który mógł jednocześnie przyjąć dwa statki pasażerskie do 50000 ton nośności. Niedługo potem, w 1969 r. ukończono kolejną związaną z nim inwestycję.

W tym samym czasie, gdy na terenach należących do The Hong Kong \& Kowloon Wharf and Godown Company Ltd. prowadzono prace nad kolejnym etapem projektu Harbour City, w głębi półwyspu Koulun - na obszarze byłych koszar brytyjskich Whitfield Camp - urządzano duży park miejski (13,3 ha), który otwarto pod nazwą Kowloon Park w 1970 r. ${ }^{11}$ Chociaż znajdował się on w pewnym oddaleniu od terenów portowych, jego otwarcie można uznać za kolejny przejaw działań, tym razem ze strony władz miejskich, na rzecz przekształcenia przestrzenno-funkcjonalnego dzielnicy Tsim Sha Tsui.

Podczas gdy po zachodniej stronie półwyspu Koulun powstawało Harbour City, po jego wschodniej stronie realizowano budowę hoteli i centrum handlowego położonych na terenach dawnych magazynów portowych Holt's Wharf. Rozpoczęła się ona w 1973 r. i obejmowała dwie inwestycje: New World Centre oraz hotel The Regent Hong Kong (chociaż pierwszy etap inwestycji został ukończony w 1979 r., całość została oddana do użytku w kilka lat później).

Ponieważ, o czym już wcześniej wspomniano, na początku lat 70. XX w. spadło znaczenie transportu kolejowego w Hongkongu, w 1975 r. zamknięty został dworzec kolejowy Kowloon Station (tym samym stacją końcową Kowloon-Canton Railway stała się oddalona o kilka kilometrów Hung Hom Station), którego budynek w 1977 r. został ostatecznie zburzony (pozostawiono jedynie wieżę zegarowa, którą uznano za cenny zabytek i symbol architektoniczny Koulunu). Równocześnie podjęto prace nad likwidacją torów kolejowych między dawną Kowloon Station a Hung Hom Station, które ostatecznie rozebrano w $1978 \mathrm{r}$.

Również w 1977 r. w sąsiedztwie terminalu morskiego ukończono (połączony z nim naziemną galerią) 18-piętrowy budynek Ocean Centre, który dzięki swoim 112 sklepom stał się największym centrum handlowym w ów-

${ }^{11} \mathrm{http} / / /$ www.lcsd.gov.hk/parks/kp/en (20.10.2011). 
czesnym Hongkongu' ${ }^{12}$. Podobnie jak i Ocean Terminal należał on do koncernu The Hong Kong \& Kowloon Wharf and Godown Company Ltd.

Rok 1979 r. przyniósł kolejną inwestycję, tym razem powstałą z inicjatywy władz miejskich, a mianowicie otwarcie stacji metra MTR Tsim Sha Tsui Station. Aby zrekompensować w pewnym stopniu uciążliwości komunikacyjne związane z likwidacją Kowloon Station, postanowiono w jak największej części włączyć MTR Tsim Sha Tsui Station w otaczające je kwartały już istniejącej i dopiero powstającej zabudowy, budując aż 13 wejść do metra.

Jednak za przełomowy $\mathrm{w}$ historii przemian przestrzenno-funkcjonalnych dzielnicy Tsim Sha Tsui moment należy uznać 1980 r., kiedy w miejscu, gdzie jeszcze kilka lat wcześniej znajdowały się tereny Kowloon Station, dokładnie naprzeciwko historycznego hotelu The Peninsula Hong Kong, otwarto nowoczesne $\mathrm{w}$ treści i formie muzeum poświęcone badaniom kosmicznym (rys. 2). Z dzisiejszej perspektywy oddanie do użytku (budowanego od 1977 r.) Hong Kong Space Museum trzeba uznać za pierwszy krok na drodze przekształcania dawnych terenów portowo-kolejowych w południowej części Tsim Sha Tsui $\mathrm{w}$ dzielnicę aktywności turystycznej zgodnej z założeniami koncepcji festival market place. Należy szczególnie podkreślić, że o ile dotychczasowe inwestycje $w$ ramach rewitalizacji Tsim Sha Tsui były prowadzone przez kapitał prywatny, Hong Kong Space Museum (urządzone na powierzchni $\left.8000 \mathrm{~m}^{2}\right)^{13}$ powstało z inicjatywy władz i było administrowane przez Radę Miasta (Urban Council, a właściwie przez jej Urban Services Department).

Niedługo po zbudowaniu i oddaniu do użytku Hong Kong Space Museum w południowo-zachodniej części dzielnicy Tsim Sha Tsui, wzdłuż biegnącej równolegle do terenów portowych Canton Road, w 1982 r. ukończono kolejne inwestycje składające się na projekt Harbour City. Były to trzy należące do systemu Marco Polo Hotels hotele - obecne The Marco Polo Hong Kong Hotel, Gateway Hong Kong Hotel i Prince Hong Kong Hotel oraz trzy biurowce (World Commerce Centre, World Finance Tower North i World Finance Tower South). Wszystkie te obiekty, które zostały zbudowane w 1982 r., należały również do The Hong Kong \& Kowloon Wharf and Godown Company Ltd.

W tym samym roku na terenach byłej Holt's Wharf, w bezpośrednim sąsiedztwie Hong Kong Space Museum, ukończono New World Centre (w jego skład wchodził 545-pokojowy Renaissance Kowloon Hotel, budynek biu-

${ }^{12} \mathrm{http}: / /$ www.oceanterminal.com.hk/index.php?id=9 (20.10.2011)

${ }^{13} \mathrm{http}: / /$ www.lcsd.gov.hk/ce/Museum/Space/textonly/e_index.htm (21.10.2011). 
rowo-apartamentowy oraz galeria handlowa $\mathrm{z}$ ponad $50 \mathrm{sklepami}^{14}$ ) oraz otwarto hotel The Regent Hong Kong ${ }^{15}$.

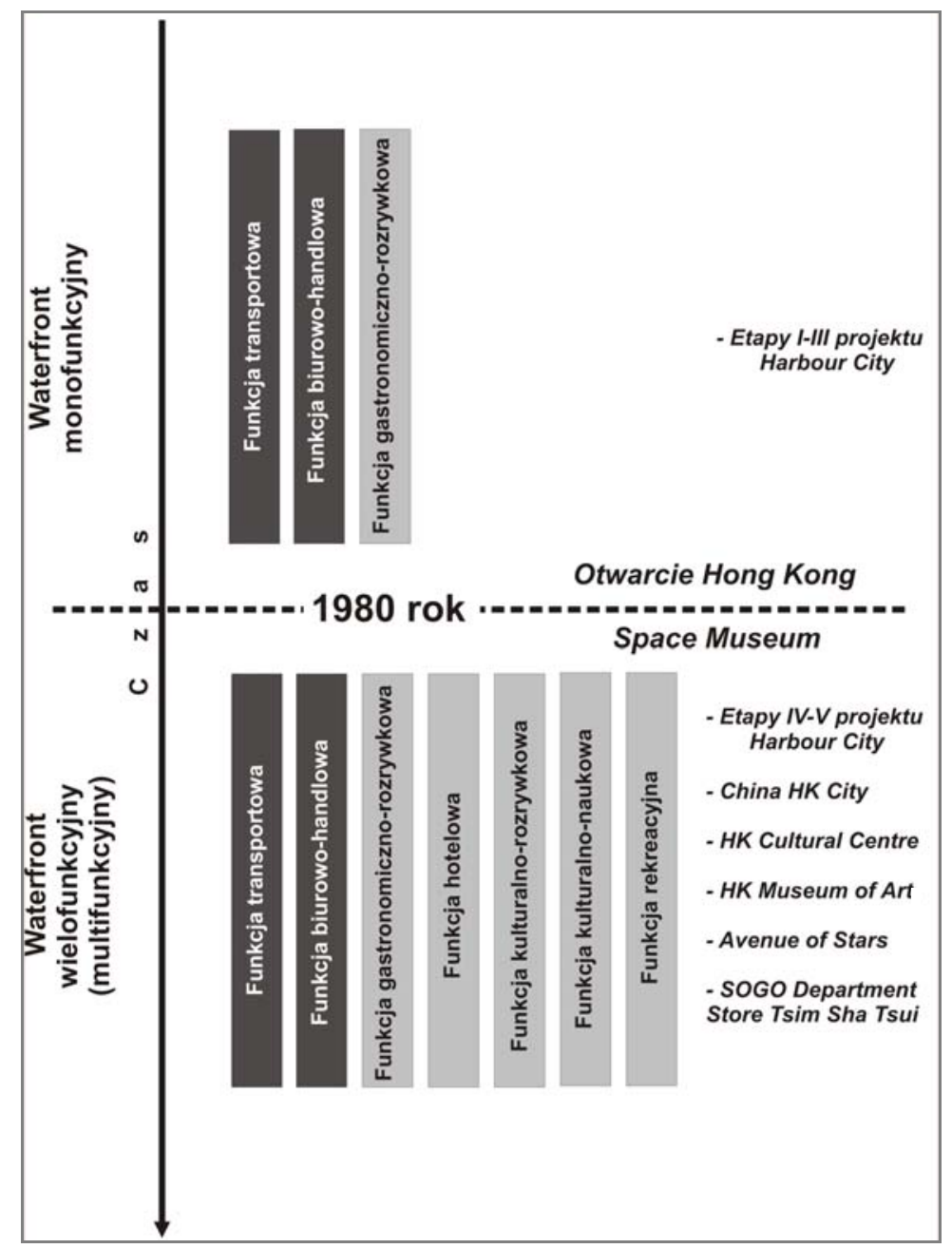

Rys. 2. Schemat rozwoju i zmiany funkcji Tsim Sha Tsui Waterfront w Koulunie (Hongkong): przejście od modelu o dominacji funkcji transportowej i biurowo-handlowej do modelu wielofunkcyjnego z silnie zaznaczoną funkcją turystyczno-rekreacyjną i kulturalną Źródło: opracowanie autora

${ }^{14} \mathrm{http}: / /$ www.frommers.com/destinations/hongkong/H37270.html (20.10.2011).

${ }_{15}$ W 2001 r. został sprzedany koncernowi Six Continents Plc. (obecnie system InterContinental Hotels Group Plc.) http://en.wikipedia.org/wiki/InterContinental_Hong_Kong (21.10.2011). 
W 1983 r. przy Canton Road ukończono kolejny biurowiec (New T\&T Building), co stanowiło zakończenie IV etapu projektu Harbour City. Nie oznaczało to jednak zrealizowania całego przedsięwzięcia, gdyż do zabudowy pozostawały jeszcze tereny bezpośrednio przylegające do morza (na północ od Ocean Centre) oraz położony na samej północy fragment terenu należący do The Hong Kong \& Kowloon Wharf and Godown Company Ltd.

W tym samym czasie, gdy The Hong Kong \& Kowloon Wharf and Godown Company Ltd. oraz New World Development Company Ltd. zakończyły inwestycje w południowo-zachodniej i południowej części dzielnicy Tsim Sha Tsui (jak wspomniano, w przypadku The Hong Kong \& Kowloon Wharf and Godown Company Ltd. nie oznaczało to całkowitego zakończenia działań zmierzających do zabudowy należącej do niego części terenów portowych), naprzeciwko Kowloon Park zaczęto realizować projekt nazwany China Hong Kong City. Miał on powstać między Canton Road a wodami Victoria Harbour na terenie należącym do firmy deweloperskiej Tsim Sha Tsui Properties Ltd., która wchodziła w skład wielkiego koncernu hongkongsko-singapurskiego Sino Group. Zespół China Hong Kong City miał składać się z siedmiu budynków: pięć biurowców (China Hong Kong City 1, 2, 3 oraz 5 i 6), a także (połączonych ze sobą) dwóch budynków przeznaczonych na hotele (The Royal Pacific Towers i The Royal Pacific Hotel). Podobnie jak i sąsiednie Harbour City, wszystkie budynki China Hong Kong City zostały zaprojektowane przez pracownię Wong \& Ouyang (HK) Ltd. Trwająca kilka lat inwestycja China Hong Kong City - położona między terenami Harbour City (na południu) i siedzibą straży pożarnej (Tsim Sha Tsui Fire Station na północy) - została ukończona w 1988 r. Spośród otaczającej je zabudowy budynki China Hong Kong City wyróżniały (i wyróżniają) się utrzymaną w złotym kolorze elewacją.

Niedługo po zakończeniu budowy China Hong Kong City w 1989 r. w południowej części dzielnicy Tsim Sha Tsui, w sąsiedztwie Hong Kong Space Museum (na zachód od niego) i tuż obok odnowionej zabytkowej wieży Tsim Sha Tsui Clock Tower (jedynej pozostałości Kowloon Station), oddano do użytku kolejny obiekt kulturalny - budowane od 1984 r. na obszarze zajmującym 5,2 ha centrum kulturalno-rozrywkowe Hong Kong Cultural Centre (tab. 2).

Również w 1989 r. - w położonym niedaleko (a nawet sąsiadującym przez ulicę z China Hong Kong City) - Kowloon Park otwarto zespół basenów o nazwie Kowloon Park Swimming Pool oraz ośrodek rekreacyjno-sportowy Kowloon Park Sports Centre. Powstanie zespołu basenów (zdolnych pomieścić jednocześnie 1530 osób), które rocznie są odwiedzane przez ok. 1 mln turystów, spowodowało jeszcze bardziej podniesienie atrakcyjnoś- 
ci z punktu widzenia rekreacji tej części Koulunu, dotychczas pełniącego głównie funkcje portowo-handlowe ${ }^{16}$.

Tabela 2. Podstawowe dane dotyczące centrum kulturalno-rozrywkowego Hong Kong Cultural Centre w Koulunie (Hongkong) w 2011 r.

\begin{tabular}{|l|c|}
\hline \multicolumn{1}{|c|}{ Wyszczególnienie } & Wielkość/liczba \\
\hline Sala koncertowa (Concert Hall) & 2019 miejsc \\
\hline Duża sala teatralna (Grand Theatre) & 1734 miejsca \\
\hline Mała sala teatralna (Studio Theatre) & od 303 do 496 miejsc \\
\hline Sala wystawowa & $287 \mathrm{~m}^{2}$ \\
\hline Foyer (przeznaczone na wystawy) & 4 \\
\hline Pracownie & 653000 \\
\hline Liczba widzów (sezon 2010/2011) & 740 \\
\hline Liczba spektakli (sezon 2010/2011) & 882,4 \\
\hline Przeciętna liczba widzów na spektaklu & \\
\hline
\end{tabular}

Źródło: opracowano na podstawie: http://www.lcsd.gov.hk/CE/CulturalService/HKCC/en/ about/ intro.html (20.10.2011), http//www.lcsd.gov.hk/en/ppr_statistic_cs.php (20.10.2011).

W 1991 r. w sąsiedztwie Hong Kong Cultural Centre oraz zbudowanego kilkanaście lat wcześniej Hong Kong Space Museum ukończono budowę nowego obiektu kulturalnego - Hong Kong Museum of Art. Podobnie jak oba wymienione wcześniej obiekty, powstało ono z inicjatywy i z funduszy Rady Miasta i zaczęło prezentować zbiory, które do tej pory tylko częściowo mogły być eksponowane w (powstałym jeszcze w 1962 r.) niewielkim muzeum ulokowanym w siedzibie władz miejskich (City Hall) w Victorii (tab. 3) ${ }^{17}$.

Tabela 3. Odwiedzający muzea położone na obszarze Tim Sha Tsui Waterfront w Koulunie (Hongkong) w latach 2008-2011

\begin{tabular}{|c|c|c|c|c|c|c|}
\hline \multirow{3}{*}{ Muzeum } & \multicolumn{6}{|c|}{ Sezon } \\
\hline & \multicolumn{2}{|c|}{$2008 / 2009$} & \multicolumn{2}{|c|}{$2009 / 2010$} & \multicolumn{2}{|c|}{$2010 / 2011$} \\
\hline & liczba & $\%$ & liczba & $\%$ & liczba & $\%$ \\
\hline Hong Kong Space Museum & 570000 & 13,1 & 658000 & 15,2 & 774000 & 15,2 \\
\hline Hong Kong Museum of Art & 295000 & 6,8 & 338000 & 7,8 & 358000 & 7,0 \\
\hline Razem & 865000 & 19,9 & 996000 & 23,0 & 1132000 & 22,2 \\
\hline $\begin{array}{l}\text { Wszystkie muzea publiczne } \\
\text { w Hongkongu }\end{array}$ & 4352000 & 100,0 & 4331000 & 100,0 & 5099000 & 100,0 \\
\hline
\end{tabular}

Źródło: opracowano na podstawie http//www.lcsd.gov.hk/en/ppr_statistic_cs.php (20.10.2011).

${ }^{16}$ http://en.wikipedia.org/wiki/Kowloon_Park (20.10.2011).

17 http://www.lcsd.gov.hk/ce/Museum/Arts/english/aboutus/aboutus.html (20.10.2011). 
Ukończenie Hong Kong Museum of Art miało duże znaczenie chociażby $\mathrm{z}$ tego powodu, że pozwoliło na dalsze (jak się okazało, jeszcze nie ostateczne) urządzenie terenów wzdłuż morza w miejscu wcześniej zajmowanym przez nabrzeża Holt's Wharf i tereny kolejowe Kowloon Station. W jego sąsiedztwie utworzono kolejne tereny zieleni (wcześniej niewielki park powstał między gmachem Hong Kong Cultural Centre a brzegiem cieśniny Victoria Harbour), które oddzielały nowe centrum kulturalno-rozrywkowe i kulturalno-naukowe (z powodu Hong Kong Space Museum) Koulunu od zabudowań komercyjno-hotelowych wzniesionych przez New World Development Company Ltd. Tym samym można uznać, że otwarcie Hong Kong Museum of Art oznaczało zakończenie działań inwestycyjnych Rady Miasta, aby najbardziej na południe wysuniętą część półwyspu Koulun przekształcić zgodnie z ideą festival market place.

Jednak utworzenie w południowej części dzielnicy Tsim Sha Tsui „dzielnicy aktywności turystycznej", podobnie jak i wcześniej ukończone projekty stricte komercyjne, nie oznaczało końca przekształceń przestrzenno-funkcjonalnych w tej części Koulunu. Po oddaniu do użytku (jeszcze w 1990 r.) zbudowanego na jednym z wychodzących w morze nabrzeży Pacific Club Kowloon, w 1994 r. - w ramach kolejnego etapu inwestycji Harbour City - ukończono dwa bliźniacze budynki (36 pięter każdy) nazwane The Gateway Tower $1 \mathrm{i}$ The Gateway Tower 2. Powstały one na parcelach położonych między dotychczasową zabudową Harbour City a - należącym już do innego inwestora - China Hong Kong City, co spowodowało wypełnienie niezabudowanej dotychczas przestrzeni wzdłuż Canton Road i połączenie Harbour City i China Hong Kong City w jedną całość (co prawda nie pod względem własności, ale z punktu widzenia przestrzenno-funkcjonalnego).

Ukończenie biurowców The Gateway Tower 1 i 2 było wstępem do kolejnego etapu prac nad Harbour City. Trwały one kilka lat i zakończyły się dopiero pod koniec lat 90. oddaniem do użytku wznoszących się nad samym morzem trzech kolejnych biurowców - The Gateway Tower 3 Prudential Tower, The Gateway Tower 5 (oba ukończone w 1998 r.) oraz The Gateway Tower 6 (zbudowany w 1999 r.). Oznaczało to zakończenie, po ponad 33 latach, projektu nazwanego Harbour City, na który składa się m.in. 1457 pokoi hotelowych, ponad 700 sklepów, 500 apartamentów oraz 2000 miejsc parkingowych.

Zakończenie projektu Harbour City można uznać za niemal ostateczne zamknięcie trwającego kilkadziesiąt lat procesu restrukturyzacji terytorialnej południowej części półwyspu Koulun, którego następstwem było powstanie Tsim Sha Tsui Waterfront (rys. 3). Zrealizowane już w XXI w. inwestycje zbudowanie w 2004 r. z inicjatywy władz Hongkongu (Leisure and Cultural 


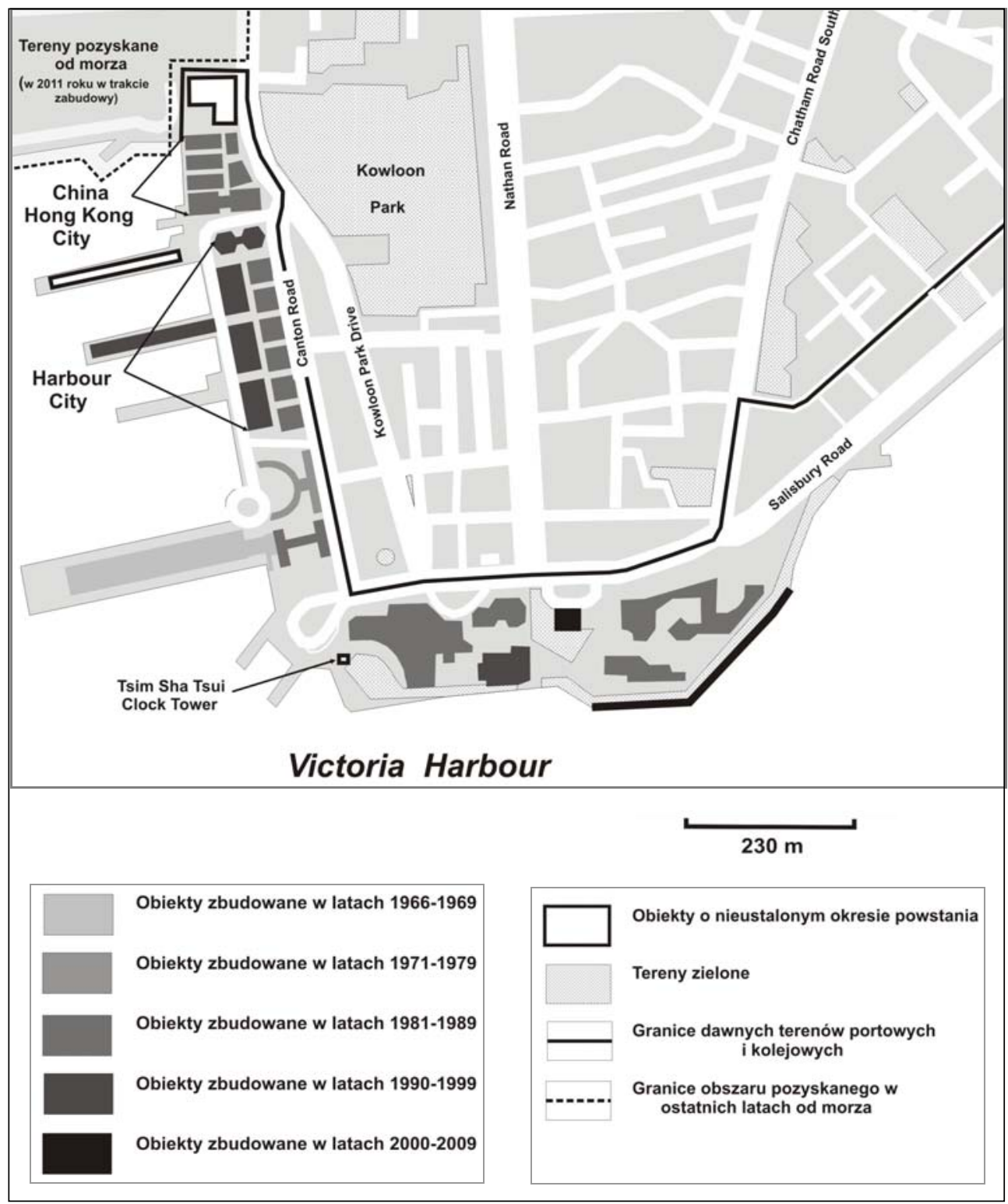

Rys. 3. Etapy powstawania Tsim Sha Tsui Waterfront w Koulunie (Hongkong) w latach 1966-2009

Źródło: opracowanie autora

40 WARSZTATYZ GEOGRAFII TURYZMU 
Services Department, który w 2000 r. przejął związane z kulturą, rozrywką i wypoczynkiem zadanie dawnego Urban Services Department) nadmorskiej promenady nazwanej Aleją Gwiazd (Aveunue of Stars) oraz otwarcie w roku 2005 dużej galerii handlowej (praktycznie zbudowanej pod ziemią i połączonej z otwartą w 2004 r. stacją metra MTR East Tsim Sha Tsui Station) SOGO Department Store Tsim Sha Tsui (kapitał japoński) - miały jednak drugorzędny charakter, chociaż pierwsza $\mathrm{z}$ nich stała się jedną $\mathrm{z}$ większych w Hongkongu atrakcji turystycznych, a druga w istotnym stopniu zwiększyła znaczenie handlowe dzielnicy Tsim Sha Tsui.

W kilka lat później - w 2009 r. - w bezpośrednim sąsiedztwie inwestycji składających się na Tsim Sha Tsui Waterfront - naprzeciwko Hong Kong Cultural Centre - ukończono prace konserwatorskie i modernizacyjne na terenie dawnego Marine Police Headquarters Compound (uznanego w 1994 r. za obiekt zabytkowy). W ramach tych prac odnowiono zabytkowy budynek brytyjskiej policji portowej, zwany Hullett House, dawną siedzibę straży pożarnej (Old Kowloon Fire Station) oraz Signal Tower. Całość - nazwana 1881 Heritage - została poddana rewitalizacji z inicjatywy władz Hongkongu, które w 2003 r. oddały nieruchomość w dzierżawę na 50 lat spółce Flying Snow Ltd. (związanej z wielką firmą deweloperską Cheung Kong Holdings Ltd.) ${ }^{18}$. Poza urządzonym w Houllett House hotelu typu boutique (o nazwie Hullett House Hotel) w skład 1881 Heritage wchodzą drogie restauracje i sklepy (głównie z markową odzieżą) oraz nieduży park.

Błędem byłoby jednak sądzić, iż ukończenie promenady nadmorskiej Avenue of Stars czy powstanie 1881 Heritage całkowicie zakończyło proces transformacji przestrzenno-funkcjonalnej południowej części półwyspu Koulun w ramach tworzenia Tsim Sha Tsui Waterfront (rys. 4). 31 marca 2010 r. zakończyło swoją 28-letnią działalność New World Centre, odnośnie do którego zapadła decyzja o wyburzeniu ${ }^{19}$. W planach jest zbudowanie na jego miejscu 70-kondygnacyjnego hotelu, oraz skrzydła zajmowanego przez apartamenty i centrum handlowe (TST... 2009). Jednak do jesieni 2011 r. nie zapadła jeszcze ostateczna decyzja $w$ tej kwestii, gdyż zgodnie $z$ przyjętymi w 2008 r. przez zajmujący się planowaniem miejskim Town Planning Board wskazaniami (Stricter rules... 2010):

- $\quad$ nowe budynki w nadwodnej części Tsim Sha Tsui mają mieć co najwyżej wysokość mieszczącą się między $60 \mathrm{~m}$ a $130 \mathrm{~m}$ (proponowany hotel ma mieć $265 \mathrm{~m}$ );

\footnotetext{
${ }^{18} \mathrm{http} / / /$ en.wikipedia.org/wiki/Former_Marine_Police_Headquarters_Compound (21.10.2011).

${ }^{19} \mathrm{http}: / /$ en.wikipedia.org/wiki/New_World_Centre (21.10.2011).
} 


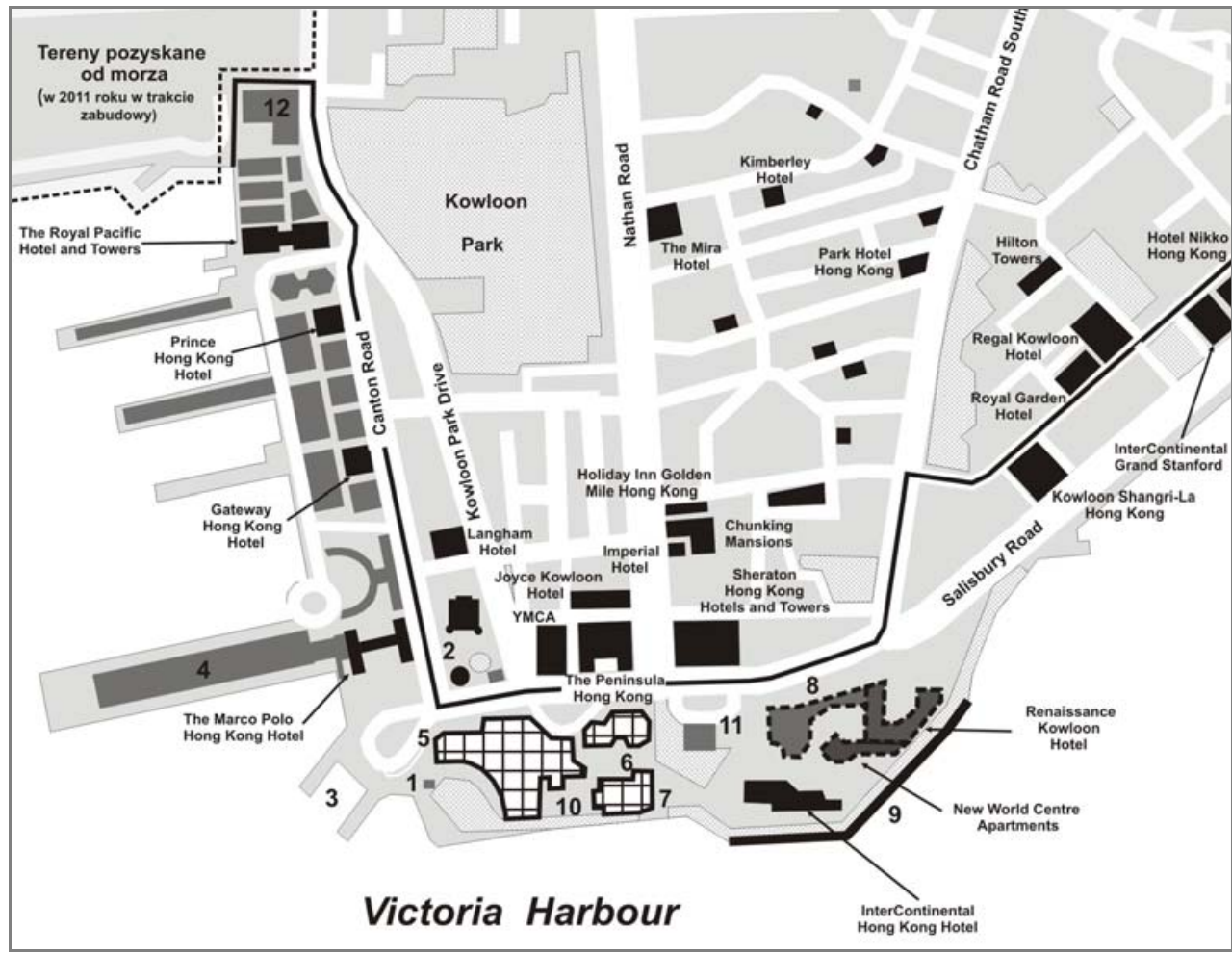

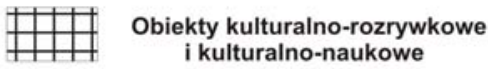

i kulturalno-naukowe
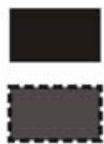

Obiekty hotelowe (w 2011 roku w trakcie rozbiórki)

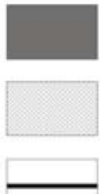

Inne obiekty

Tereny zielone

Granice dawnych terenów portowych

$$
\text { i kolejowych }
$$

Granice obszaru pozyskanego w ostatnich latach od morza

\section{$230 \mathrm{~m}$}

\section{Oznaczone obiekty}

1 - Tsim Sha Tsui Clock Tower

2 - 1881 Heritage (dawne Marine Police Headquarters Compound)

3 - Star Ferry Pier

4 - Ocean Terminal

5 - Hong Kong Culture Centre

6 - Hong Kong Space Museum

7 - Hong Kong Museum of Art

8 - New World Centre Aia Tower

9 - Avenue of Stars

10 - Miejsce imprez (plaza)

11 - SOGO Department Store Tsim Sha Tsui

12 - Tsim Sha Tsui Fire Station

Rys. 4. Obiekty o funkcjach turystyczno-rekreacyjnych i kulturalnych w strefie Tsim Sha Tsui Waterfront i na przylegających do niej terenach w Koulunie (Hongkong) w 2011 r. Źródło: opracowanie autora 
- co najwyżej $65 \%$ działki budowlanej może być zabudowana, a $20 \%$ terenu powinna zajmować zieleńn ${ }^{20}$.

Tabela 4. Liczba pokoi i apartamentów w hotelach położonych w strefie Tsim Sha Tsui Waterfront w Koulunie (Hongkong) w 2011 r.

\begin{tabular}{|l|c|l|}
\hline \multicolumn{1}{|c|}{ Hotel $^{*}$} & $\begin{array}{c}\text { Pokoje } \\
\text { i apartamenty }\end{array}$ & \multicolumn{1}{c|}{ System hotelowy } \\
\hline Gateway Hong Kong Hotel & 399 & Marco Polo Hotels \\
\hline Prince Hong Kong Hotel & 393 & Marco Polo Hotels \\
\hline The Marco Polo Hong Kong Hotel & 665 & Marco Polo Hotels \\
\hline InterContinental Hong Kong & 582 & InterContinental Hotels \& Resorts \\
\hline The Royal Pacific Hotels \& Towers & 673 & Sino Group of Hotels \\
\hline Razem & 2712 & $x$ \\
\hline
\end{tabular}

* Bez nieczynnego od 2010 r. Renaissance Kowloon Hotel.

Źródło: opracowano na podstawie: http://www.ichotelsgroup.com/intercontinental/en/gb/ locations/ overview/hongkong (20.10.2011), http://www.marcopolohotels.com/en/corporate/about_us/development/ world_class_asian_hospitality.html (20.10.2011), http://www.sino-hotels.com/The_Royal_Pacific_Hotel_ and_Towers/en/default.aspx (20.10.2011).

Niezależnie jednak od ostatecznego finału dyskusji między deweloperem a władzami na temat przyszłości New World Centre, zburzenie obiektów wzniesionych jeszcze w $1982 \mathrm{r}$. i powstanie zamiast nich innych budynków, będzie bez wątpienia nowym etapem w procesie kształtowania się w południowej części Koulunu strefy nadwodnej nazywanej Tsim Sha Tsui Waterfront. Należy liczyć się, że w niedługim czasie podobny los może dotknąć budynki wzniesione w latach 80. XX w. w Harbour City oraz w China Hong Kong City, co wynika z polityki miejskiej przyjętej przez władze Hongkongu.

\section{Podsumowanie}

Czy Tsim Sha Tsui Waterfront w Koulunie (Hongkong) można uznać za dobry przykład połączenia koncepcji festival market place z koncepcją water-

${ }^{20}$ Zgodnie z przygotowanym projektem nowy New World Centre ma mieć powierzchnię $127858 \mathrm{~m}^{2}$, przy czym 66997 m² będzie zajmować część hotelowa (610 pokoi), 32298 m² część mieszkaniowa, 24063 $\mathrm{m}^{2}$ część handlowa, a $4500 \mathrm{~m}^{2}$ zieleń. Budynek ma mieć także jedną kondygnację pod ziemią (http://www. skyscrapercity.com/showthread.php?t=766852\&page=5, 21.10.2011). 
frontu? Wydaje się, że tak, o czym mogą świadczyć przede wszystkim następujące powody:

- w dzielnicy Tsim Sha Tsui doszło do znacznego ograniczenia funkcji związanych z portem; obecność Ocean Terminal - który obsługuje głównie statki odbywające rejsy wycieczkowe (cruising) - dobrze ilustruje zastąpienie funkcji związanych $\mathrm{z}$ transportem przez funkcję turystyczną;

- wzniesienie $\mathrm{w}$ miejscu, gdzie wcześniej były tereny zajmowane przez dworzec kolejowy i stację towarową (z racji sąsiedztwa portu) obiektów związanych z kulturą i rozrywką (dwa muzea, centrum kulturalno-rozrywkowe), które cieszą się wielką popularnością wśród turystów i mieszkańców Hongkongu, świadczy o zastosowaniu w praktyce koncepcji festival market place;

- zbudowanie na dawnych terenach portowo-kolejowych licznych hoteli ${ }^{21}$ jest kolejnym dowodem na duże znaczenie w nadwodnej części Tsim Sha Tsui funkcji turystycznej;

- również inne inwestycje - np. tzw. Aleja Gwiazd, tereny zielone, miejsce imprez w sąsiedztwie muzeów i Hong Kong Cultural Centre - podkreślają turystyczną oraz rekreacyjną funkcję Tsim Sha Tsui Waterfront;

- last but not least - dopełnienie funkcji stricte turystycznych (hotele), kulturalnych, rozrywkowych i rekreacyjnych licznymi restauracjami, galeriami handlowymi, biurowcami (w których na ogół mieszczą się siedziby korporacji o globalnym zasięgu) oraz sprawnie działającym transportem miejskim (dwie stacje metra, przystań promowa, a także liczne linie autobusowe) również pozostaje $\mathrm{w}$ zgodzie $\mathrm{z}$ koncepcją FMP.

Pojawia się także następujące pytanie. Czy Tsim Sha Tsui Waterfront można uznać za przykład działań, które będzie właściwą receptą na odniesienie sukcesu? Również odpowiedź na to pytanie powinna brzmieć twierdząco.

Po pierwsze, w latach 60. XX w. - wobec utraty znaczenia urządzeń portowych zlokalizowanych w południowej części Koulunu i likwidacji wiodącej do Kowloon Station linii kolejowej - władze Hongkongu i firmy prywatne będące właścicielami terenów portowych i kolejowch znalazły się w sytuacji, która nie dawała zbyt wiele możliwości wyboru. Alternatywa, jaka się wówczas pojawiła, była następująca: albo dawne tereny portowo-kolejowe, sąsiadujące ze ścisłym centrum Koulunu zaczną w sposób planowy zmieniać

${ }^{21} \mathrm{~W}$ tym miejscu należy dodać, że w odległości mniejszej niż $500 \mathrm{~m}$ od granic Tsim Sha Tsui Waterfront są zlokalizowane hotele, $\mathrm{w}$ których jest łącznie kilka tysięcy pokoi. $\mathrm{W}$ bezpośrednim sąsiedztwie znajdują się m.in. wspomniany The Peninsula Hong Kong (300 pokoi i apartamentów), jak również Sheraton Hong Kong Hotels \& Towers (782 pokoje i apartamenty) oraz Kowloon Shangri-La Hong Kong (688 pokoi i apartamentów). 
swoją funkcję, albo zmiany będą miały charakter procesu żywiołowego. Drugi scenariusz nie wchodził w grę, m.in. dlatego, iż Hongkong - uważany co prawda przez Miltona Friedmana za doskonały przykład gospodarki neoliberalnej (FRIEDMAN, FRIEDMAN 1990, s. 34) ${ }^{22}$ - w zakresie planowania przestrzennego i polityki miejskiej dosyć ściśle kierował się zasadami funkcjonującymi w Wielkiej Brytanii (był zresztą w tym czasie posiadłością brytyjską), które sprowadzały się do posiadania przez sektor publiczny (władze miejskie) silnej pozycji $\mathrm{w}$ negocjacjach $\mathrm{z}$ prywatnymi inwestorami (WAI-CHUNG LAI 2001).

Po drugie, niedługo po rozpoczęciu długiego procesu restrukturyzacji terytorialnej w dzielnicy Tsim Sha Tsui w wielu miastach na świecie (zwłaszcza w Stanach Zjednoczonych) zaczęto wprowadzać w życie koncepcje planistyczne festival market place i waterfrontu. Nic więc dziwnego, że zaczęły one być realizowane również w Victorii i Koulunie.

Po trzecie, w programach rewitalizacji śródmieść wielkich aglomeracji miejskich na świecie coraz większą rolę zaczęło odgrywać wprowadzanie funkcji związanych z kultura, rozrywka, a także turystyką i rekreacją. Stało się tak również w przypadku wspomnianych Victorii i Koulunu, a w przypadku tego ostatniego - w dzielnicy Tsim Sha Tsui. Czy te działania przyniosły oczekiwany skutek? Należy przyjąć, że tak, gdyż np. oba muzea zlokalizowane $\mathrm{w}$ strefie Tsim Sha Tsui Waterfront (na 16 muzeów w Hongkongu) są odwiedzane przez ok. 1/5 wszystkich odwiedzających muzea publiczne w Hongkongu (patrz: tab. 3), promenada nadmorska Avenue of Stars jest miejscem spacerów niemal wszystkich turystów przyjeżdżających do Hongkongu, a odbywające się codziennie widowisko "światło i dźwięk" nazwane "A symphony of lights" gromadzi w nadwodnej części Tsim Sha Tsui każdego wieczoru tysiące ludzi.

Biorąc to wszystko pod uwagę należy stwierdzić, że w wyniku konsekwentnych działań, polegających na „włączaniu” kolejnych inwestycji w zakończone wcześniej nadwodne struktury przestrzenno-funkcjonalne, w południowej części półwyspu Koulun powstała nowoczesna dzielnica o bardzo zróżnicowanych funkcjach. W ten sposób, zgodnie $\mathrm{z}$ terminologią stosowaną przez KACZMAREK (2001, s. 26), przypadek Tsim Sha Tsui Waterfront należy uznać za przykład zastosowania rewitalizacji implantacyjnej (KACZMAREK 2001, 26). Jednocześnie można przyjąć, że obserwowany od kilku lat systematyczny wzrost liczby odwiedzających Hongkong (23 359000 w 2005 r. i $36030000 \mathrm{w} 2010 \mathrm{r}{ }^{23}$ ) jest po części spowodowany rozwojem funkcji tury-

\footnotetext{
22 „If you want to see capitalism in action, go to Hong Kong."

${ }^{23}$ Hong Kong in figuers... (2011).
} 
stycznych i rekreacyjnych (w szerokim znaczeniu tych terminów) w dzielnicy Tsim Sha Tsui w Koulunie.

\section{BIBLIOGRAFIA}

ASHWORTH G. J., TUNBRIDGE J. E., 2000, The tourist-historic city: retrospect and prospect of managing the heritage city, Pergamon, Amsterdam - New York.

Burtenshaw D., Bateman M., Ashworth G. J., 1991, The European city, David Fulton Publishers, London.

Clark T. N., Lloyd R., Wong K. K., Jain P., 2001, Amenities drive urban growth, American Political Science Association Annual Meeting, San Francisco, August, 2001, Urban Politics Section, Session 31-10, mpis.

COHEN-HATTAB K., 2004, Historical research and tourism analysis: the case of the tourist-historic city of Jerusalem, Tourism „Geographies”, 6, 3, s. 279-302.

FRIEDMAN M., FRIEDMAN R., 1990, Free to choose: a personal statement, Harvest Books, San DiegoNew York-London.

GETZ D., 1993, Planning for tourism business districts, „Annals of Tourism Research”, 20, 4, s. 583-600.

GRAVARI-BARBAS M., 1998, La "festival market place" ou le tourisme sur le front d'eau. Un modèle urbain américain à exporteur?, „Norois”, 45, 178, s. 261-278.

Hong Kong fabulous events \& future developments, 2004, Hong Kong Tourism Board, Hong Kong.

Hong Kong future tourism developments, 2003, Hong Kong Tourism Board, Hong Kong.

Hong Kong in figuers. 2011 edition, 2011, Government of the Hong Kong Special Administrative Region, Census and Statistics Department Hong Kong Special Administrative Region, Hong Kong.

Hong Kong museums \& heritage, 2003, Hong Kong Tourism Board, Hong Kong.

HuGHES H., 2003, Arts, entertainment and tourism, Butterworth-Heinemann, Oxford-Burlington.

KACZMAREK S., 2001, Rewitalizacja terenów poprzemystowych. Nowy wymiar w rozwoju miast, Rozprawy Habilitacyjne Uniwersytetu Łódzkiego, Wydawnictwo Uniwersytetu Łódzkiego, Łódź.

KK, 2010, Norman Foster publikuje propozycje projektowe dla dzielnicy West Kowloon (Hong Kong), http://w-a.pl/aktualnosci.php?artykul=1717 (13.03.2011).

KOWALCZYK A., 2005, Nowe formy turystyki miejskiej, „Prace i Studia Geograficzne”, 35, pt. Zmiany przestrzenne i funkcjonalne obszarów miejskich, Wydział Geografii i Studiów Regionalnych, Uniwersytet Warszawski, Warszawa, s. 155-197.

KOWALCZYK A., DEREK M., 2010, Zagospodarowanie turystyczne, Wydawnictwo Naukowe PWN, Warszawa.

LAW CH. M., 1992, Urban tourism and its contribution to economic regeneration, "Urban Studies”, 29, 3-4, s. 599-618.

Planning study on the Harbour and its waterfront areas. Assessment of the potential of the Harbour for tourism purposes. Final report. Volume 1 - Main report, February 2003, Hong Kong Tourism Board, Planning Department, Shankland Cox Asia Ltd., Hong Kong, http://www.pland. gov.hk/pland_en/p_study/comp_s/harbour/harbour_finalreport/contents.htm\#appendice, 01.04.2011. 
STANSFIELD C., RICKERT J., 1970, The recreational business district, „Journal of Leisure Research", 2, 4, s. 213-225.

Stricter rules proposed for tall office blocks in Tsim Sha Tsui, "South China Morning Post", 4 June 2010, http://www.skyscrapercity.com/showthread.php?t=766852\&page=5 (21.10.2011).

Tölle A., 2010, Restrukturyzacja miejskich obszarów nadwodnych. Aspekty urbanistyczne, zarzadzajace i społeczno-kulturowe, Biuletyn Instytutu Geografii Społeczno-Ekonomicznej i Gospodarki Przestrzennej Uniwersytetu im. Adama Mickiewicza, ser.: „Rozwój Reigonalny i Polityka Regionalna", 10, Poznań.

TST towers skewer new height limits, „South China Morning Post”, 23 August 2009, http://www. skyscrapercity.com/showthread.php?t=766852\&page=2 (21.10.2011).

VOASE R., 1997, The role of flagship cultural project in urban regeneration: a case study and commentary, „Managing Leisure”, 2, 4, s. 230-241.

WaI-CHUnG LAI L., 2001, Zoning and property rights. A Hong Kong case study, Hong Kong University Press, Aberdeen, Hong Kong.

WŁODARCZYK B., 2009, Przestrzeń turystyczna. Istota, koncepcje, determinanty rozwoju, Rozprawy Habilitacyjne Uniwersytetu Łódzkiego, Wydawnictwo Uniwersytetu Łódzkiego, Łódź.

\section{Strony internetowe}

http://en.wikipedia.org/wiki/Chungking_Mansions (20.10.2011).

http://en.wikipedia.org/wiki/Clock_Tower,_Hong_Kong (20.10.2011).

http://en.wikipedia.org/wiki/Festival_marketplace (15.10.2011).

http://en.wikipedia.org/wiki/Former_Marine_Police_Headquarters_Compound (20.10.2011).

http://en.wikipedia.org/wiki/InterContinental_Hong_Kong (21.10.2011).

http://en.wikipedia.org/wiki/Kowloon_Park (20.10.2011).

http://en.wikipedia.org/wiki/New_World_Centre (21.10.2011).

http://en.wikipedia.org/wiki/Rouse_Company (15.10.2011).

http://en.wikipedia.org/wiki/Swire_Group (21.10.2011).

http://en.wikipedia.org/wiki/The_Peninsula_Hong_Kong (20.10.2011).

http://pl.wikipedia.org/wiki/Waterfront (15.10.2011).

http://www.emporis.com/city/101300?nav=worldmap_ci_bu_ob_li\&id=101300\&bt=47\&ht=2\&s ro=1\&lng=3 (21.10.2011).

http://www.faneuilhallmarketplace.com/?q=history (17.10.2011).

http://www.frommers.com/destinations/hongkong/H37270.html (20.10.2011).

http://www.ichotelsgroup.com/intercontinental/en/gb/locations/overview/hongkong (20.10.2011).

http://www.lcsd.gov.hk/CE/CulturalService/HKCC/en/about/intro.html (20.10.2011).

http://www.lcsd.gov.hk/ce/Museum/Arts/english/aboutus/aboutus.html (20.10.2011).

http://www.lcsd.gov.hk/ce/Museum/Space/textonly/e_index.htm (21.10.2011).

http//www.lcsd.gov.hk/en/ppr_statistic_cs.php (20.10.2011).

http://www.lcsd.gov.hk/parks/kp/en (20.10.2011).

http://www.marcopolohotels.com/en/corporate/about_us/development/world_class_asian_hos pitality.html (20.10.2011).

http://www.oceanterminal.com.hk/index.php?id=9 (20.10.2011).

http://www.sino-hotels.com/The_Royal_Pacific_Hotel_and_Towers/en/default.aspx

(20.10.2011).

http://www.skyscrapercity.com/showthread.php?t=766852\&page=5 (21.10.2011). 